\title{
RELATING INNOVATIVENESS TO CUSTOMER'S SATISFACTION IN PUBLIC-SECTOR BANKS: MODERATING ROLE OF TOP-MANAGEMENT SUPPORT
}

\author{
Muhammad Faisal Sultan ${ }^{*}$, Javed Nabi Khoso', \\ Shuja Ahmed Mahesar ${ }^{3}$, and Baqir Husnain ${ }^{4}$
}

\begin{abstract}
In recent years, business organizations have been compelled to compete in the competitive environment and to advance innovativeness, provide improved product and service quality and respond effectively to dynamic demands and preferences. Studies on corporate entrepreneurship are now common in Pakistan. Although most of the studies tend to explore the link between corporate entrepreneurship \& a firm's growth, however, there is also a need to check the relationship of corporate entrepreneurship with other elements of growth. Therefore, this study tries to explore the effect of innovation as a part of corporate entrepreneurship on customer's satisfaction with the reference of middle-level management of public sector banks. Data was collected through a structured questionnaire which was analyzed through SMART-PLS. The results indicate that there is a definite relationship between corporate entrepreneurship and customer satisfaction, whereas the support of top management is also an imperative variable in the context of public sector banks. This study, therefore, will be beneficial for increasing understanding and theory building criteria. The empirical findings of the study also reflected that innovation is a significant predictor of customer satisfaction and moderation of top management support is significant to foster customer satisfaction. The study offers managerial implications and future research recommendations on the basis of the findings.
\end{abstract}

Keywords: Entrepreneurial Intention; Locus of Control; Risk Taking Propensity; Self-Confidence; Ambiguity Tolerance; Need for Achievement; Innovativeness.

\footnotetext{
${ }^{1}$ Assistant Professor, Khadim Ali Shah Bukhari Institute of Technology-KASBIT, Karachi, Pakistan. Email: mfaisal@ kasbit.edu.pk

${ }^{2}$ Fulbright Fellow, Massachusetts Institute of Technology (MIT), USA. Email: javednabikhoso@gmail.com

${ }^{3}$ Professor and Director, Pakistan Study Centre, University of Sindh, Jamshoro, Sindh, Pakistan. Email: shuja.mahesar@usindh.edu.pk

${ }^{4}$ Division Project Manager, Human Resource Development, Higher Education Commission, Pakistan. Email: baqirhusnain@hotmail.com

*Corresponding Author
} 


\section{INTRODUCTION}

Corporate Entrepreneurship (CE) is also known as entrepreneurial intrapreneurship (Demirkan, Yang, \& Jiang, 2019) and entrepreneurial orientation while application of this approach provides several benefits to the firms (Karacaoglu et al., 2013). Studies like Demirkan et al. (2019) highlighted that CE is also perceived as one of the major source of competitive advantage and also aids firms in sustaining competitive pressure (Bavil, 2017). Hence the focus towards the CE has become more extensive (Karacaoglu et al., 2013).

The initial model for CE was presented by Covin and Slevin (1991) containing three major forces i.e., innovation, risk taking and proactiveness which are still considered as the effective determinants of the phenomenon (Banda \& Kazonga, 2018). Although Demirkan et al. (2019) indicated that the literature which discusses CE is not adequately available. Moreover, reviews, discussions and patterns of CE discussed by most of the studies are consistent with businesses in developed economies (Demirkan et al., 2019 \& Kuratko, Hronby \& Covin, 2014). However, emerging markets are perceived as major source behind the world's economics and entrepreneurial efforts (Kahkha, Kahrazeh \& Armesh, 2014). Therefore, it is valid to pose questions that how $\mathrm{CE}$ activities in emerging markets are different from developed world \& how these activities may foster or hinder forces behind CE. However, substantial variation was found in culture, technology and economics in terms developed as well as developing economies (Demirkan et al., 2019).

Kuratko, Hronby, and Covin (2014) also indicated the same issue i.e., absence of corporate governance might differentiate practices of CE in emerging and developed markets (Shaikh, 2020). Thorough review of literature also suggests that most of the research work has been carried out in investigating the effect of CE on growth and profitability of the firm for e.g., Antoncic and Hisrich (2004) and Karacaoglu Bayrakdaroglu and San (2013) etc. Similarly, most of the studies from Asian and emerging markets like Sultan and Asim (2020); Kahkha et al. (2014); Umrani, Mahmood, and Ahmed (2016) and Umrani, Kura, and Ahmed (2018) also focused on effect of $\mathrm{CE}$ on firm performance. However, customer value is one of the most significant elements for company's success (Hills, Hultman \& Miles, 2008) and to cater customer needs effectively company must remain in line with customer's opinion (Lotfabadi, 2018). Hence, it is justifiable to declare severe lacking studies regarding relationship of CE on customer's satisfaction except few e.g., Hasanin (2018).

Thus, it is valid to consider Lotfabadi's (2018) assertion which mark CE as an important tool to optimize customer's satisfaction and relate it with Hasanin (2018), which highlighted the need to check the effect of CE on customer's satisfaction. Especially, in public sector banks 
the policy makers must be proactive in rendering empathy towards customers as in tough competition bank having best service quality will drive. (Hasanin, 2018).

However, studies on relationship of innovation on customers' satisfaction are very rare and systematic work is required through variation in parameters (Sharma, 2017). Therefore, this study will determine the effect of innovativeness in public sector banks of Pakistan on customers' satisfaction. Moreover, public limited companies (PLCs) are now facing more challenges as compared to the past \& CE is the tool to help these sorts of firms (Ambad \& Wahab, 2016). Thus, it is appropriate to check the effect of CE on customer satisfaction (Hasanin, 2018) with respect to public sector firms as it is not only beneficial for effective strategies but also for quality \& fostering rate of survival (Ambad \& Wahab, 2016). Therefore, there is a requirement of workable model associated with $\mathrm{CE}$ of government level companies (GLC) in Pakistan (Nayyar, 2017). However, to device research model which includes all the ingredients of $\mathrm{CE}$ is much difficult due to insufficient $\mathrm{CE}$ studies in emerging markets (Demirkan et al., 2019) \& Asia (Kuratko et al., 2014). Consequently, to develop workable model which may also be integrated to Asian \& developing countries, innovation is the only predictor or independent variable. Reasons to prefer innovation are several among them major are:

i. Innovation is a part of contemporary model of CE (Banda \& Kazonga, 2018).

ii. Innovation in GLC might induce decision making and reduce competitive pressure (Entebang \& Harrison, 2019).

iii. Continuous innovation of offerings and technologies is topline indicator of $\mathrm{CE}$ (Ambad \& Wahab, 2016) and termed as innovativeness (Ozdemirci, 2011).

Contrarily, CE cannot be incorporated effectively without optimal support from top management as it is treated as most critical hindrance to CE (MacMillan, Block \& Narasimha, 1984). In point of fact, contemporary concept requires support from top as well as middle level management to incorporate proper and effective plans (Carter \& Jones-Evans, 2006). Thus, this study seems to be a unique blend of variable as most of the times CE has been found associated with performance of the firm e.g., Sultan and Asim (2020); and Umrani, Kura, and Ahmed (2018).

Hence, study is one of the initial one which fulfill the requirement of Hasanin (2018) through linking CE with customer's satisfaction. Hence, optimal to declare study as state of art as well as pervasive one as it is not only associated with workable model of CE in GLC but also tested that in a unique way. 
Reason to pose high level of significance is presence of innovativeness as the predictor of CE is rare in emerging markets (Demirkan et al., 2019) \& Asia (Kuratko et al., 2014). Moreover, analyzing these sorts of measures with respect to public sector firms as it is not only beneficial for effective strategies but also for quality \& fostering rate of survival (Ambad \& Wahab, 2016). Therefore, it is appropriate to quote Chang (2000) who indicated that CE may be defined as the degree of innovation in firms' operations through its resources and employees (Hasanin, 2018).

Furthermore, similar has been indicated by Munoz, Sanchez, Pena and Salinero (2016), that main ingredient of entrepreneurial spirit is innovation. Similarly, it has also been perceived that launch of new or improved products or services will eventually aids to the customer's value. This topline indicator of CE (Ambad \& Wahab, 2016) termed as innovativeness (Ozdemirci, 2011) although process require support form middle as well as top management (Carter \& Jones-Evans, 2006). Though the support of top management is termed as major hindrance in the process of innovation (MacMillan et al., 1984).

$\mathrm{H}_{1} \mathrm{~A}$ : There is no relationship between innovativeness and customer satisfaction in public sector scheduled banks of Pakistan.

$\mathrm{H}_{2} \mathrm{~A}$ : Top management support does not moderate the relationship of innovativeness and customer satisfaction in public sector scheduled banks of Pakistan.

\section{METHODOLOGY}

According to Zukauskas, Vveinhardt, and Andriukaitiene (2018), scientific research philosophy encompasses choice of research strategy, defining research problem, data collection, its processing and analysis. Study also indicated that methodology is the supportive structure if research which underlines the theoretical perspective of the study. In effect, methodology is generically associated with theoretical foundation of research while research method is a systematic way to collect and analyze data. The sub-division of research methodology which provide appropriate framework is known as research design (Sileyew, 2019), however each researcher may choose own approach to conduct research (Zukauskas et al., 2018).

This study focuses specifically on the effect of innovativeness on the customer's satisfaction of public sector banks in Pakistan. Thus, the philosophy associated with this study is epistemology as there was severe lacking these types of researches which link CE with CS. Therefore, optimal to link study with epistemology to foster knowledge optimization with respect to CE and its application which is consistent with Saunders, Lewis, and Thornhill 
(2012) and Saunders, Lewis, Thornhill, and Bristow (2015). Moreover, impact of epistemology is much extensive for methodology as well as research methods as it is best for knowledge creation. Although to select best method for collection researchers have to select stance or research paradigm or stance as it is required for data collection \& analysis (Zukauskas et al., 2018).

Here the research stance is post-positivism, as it is applicable to both qualitative and quantitative research work (Saunders et al., 2009), the method for researching results is deductive; research strategy was survey (Saunders, Lewis \& Thornhill, 2009). The researcher interference is moderate, study setting was non-contrived, and type of experiment was field experiment (Sekaran \& Bougie, 2016), while time horizon was cross-sectional (Sekaran \& Bougie, 2016 \& Saunders et al., 2009) On the other hand inclusion of specific units rather than entire population is the main theme behind sampling design (Mugenda, 2003). In addition to accomplishment of research objectives the method must also decrease overall cost of data collection (Leedy \& Ormrod, 2005). Although most of the studies conducted on corporate entrepreneurship were found to be associated with non-probability sampling.

Therefore, in accordance with the approach adopted by Moghaddam, Khoakian, and Maharti (2015); Moghadam \& Salamzadeh (2018); Sebora and Theerapatvong (2010) \& Umrani, Kura, and Ahmed (2018), this study also uses the same technique of sampling. However, government level companies (GLCs) are measly inclined towards CE, thus middle level managers must also be considered in the sample (Moghaddam et al., 2015). Research population of the study includes all the public sector banks of Pakistan but in order to be specific, this study takes the reference from public sector scheduled banks. Thus, data was collected from middle management of NBP, ZTBL, First Women Bank, BoK, BoS \& BoP (State Bank of Pakistan, n.d.).

Initially, 300 questionnaires were circulated among branch managers \& operations managers to make this study consistent with customer satisfaction. Inclusion of middle level management was also consistent with Ahmed et al. (2020) and Umrani et al. (2018). However, the sample size of initial one was around 300 and the later one was 200 therefore through taking the mean of sample this study has been conducted through 250 respondents. This has been done through quota sampling which has been used by Ahmed et al. (2020). The research instrument used in this study is a blend of various studies from construct of CE on business performance and customers' satisfaction. Questionnaire addresses Ahmed et al. (2020) and Umrani et al (2020) for CE, Hasanin (2018) for CS; and Ireland, Kuratko, and Morris (2006) for TMS. All the 
elements were in the form of Likert scale with the range from 1 to 5 , where the initial point indicates least impactful and later indicates most impactful.

\section{RESULTS AND DISCUSSION}

SMART-PLS software analysis is the best solution for dealing with descriptive statistics as well as structural inferential modeling in the category of inferential statistics (Richter, Sinkovics, Ringle \& Schlagel, 2016). The software has two types of model i.e., structural (inner model) and measurement (outer model). Outer models are further classified as reflective and formative models and are suited best for different conditions (Hair et al., 2019). The model of this study is found to be reflective in nature and therefore must be analyzed as per the indication of Afthanorhan (2014) and Hair et al. (2019).

Table 1. Outer Loadings

\begin{tabular}{|c|c|c|c|c|}
\hline & Innovativeness & $\begin{array}{c}\text { Perceived } \\
\text { Customer } \\
\text { Satisfaction }\end{array}$ & $\begin{array}{c}\text { Top } \\
\begin{array}{c}\text { Management } \\
\text { Support }\end{array} \\
\end{array}$ & $\begin{array}{c}\text { Moderating } \\
\text { Effect TMS } \\
\text { PCS }\end{array}$ \\
\hline IN1 & 0.712 & & & \\
\hline IN2 & 0.850 & & & \\
\hline IN3 & 0.769 & & & \\
\hline PCS2 & & 0.720 & & \\
\hline PCS3 & & 0.695 & & \\
\hline PCS4 & & 0.764 & & \\
\hline PCS5 & & 0.704 & & \\
\hline PCS6 & & 0.699 & & \\
\hline PCS7 & & 0.731 & & \\
\hline TMS2 & & & 0.799 & \\
\hline TMS3 & & & 0.746 & \\
\hline MS4 & & & 0.731 & \\
\hline MS5 & & & 0.810 & \\
\hline $\begin{array}{l}\text { innovativeness } \\
* \text { Top Mngt. } \\
\text { Support }\end{array}$ & & & & 1.151 \\
\hline
\end{tabular}

Table 1 above indicates the outer loadings for each of the variable used in the construct and the researchers are free to include variable in the construct. However, elements having elements having values 0.5 or less must always be deleted $\& 0.60$ is the least acceptable value for inclusion of any of the element (Afthanorhan, 2014). However, the inclusion became more effective when these values approaches to 1 (Khan et al., 2019), though least value in table 1 is 0.695 and therefore there is no issue with the outer loading of any of the element. 


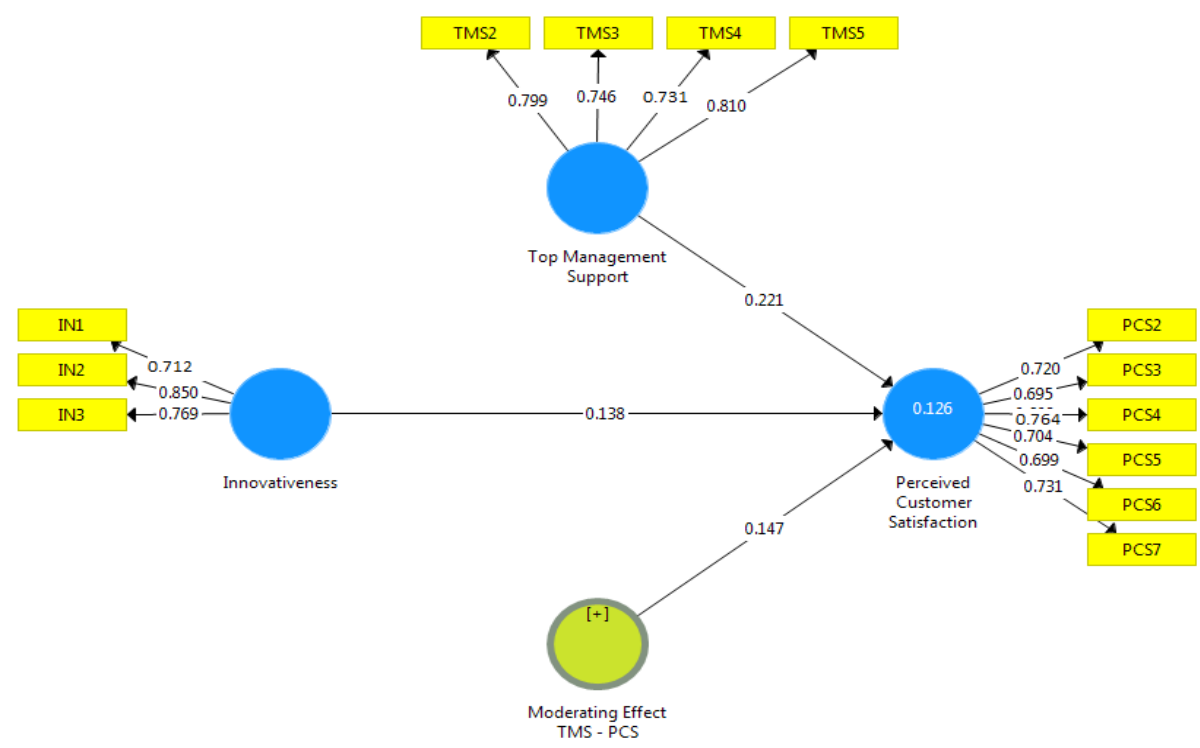

Figure 1. Outer Loadings and CFA for the Model of Innovativeness on Customer's Satisfaction

Table 2. Predictive Accuracy (Quality Criteria) - R Square

\begin{tabular}{lll}
\hline & R Square & $\begin{array}{r}\text { R Square } \\
\text { Adjusted }\end{array}$ \\
\hline Perceived Customer Satisfaction & 0.726 & 0.706 \\
\hline
\end{tabular}

Table 2 indicates the predictive accuracy through R-Square which is actually the measure of predictive variance of independent variable over the dependent through ordinary least square (Benitez, Henseler, Castillo, \& Schuberth, 2020). Interpretation is same as the multiple regression (Andreev, Heart, Moaz \& Pliskin, 2009) and the minimum value required for highlighting relationship between is 0.26 (Cheah, Memon, Chuah, Ting, \& Ramayah, 2018). Though, value of R-Square for this study is $0.726 \&$ therefore the model is moderate fit as the value of predictive accuracy is above than 0.5 although just on the lower side then the substantial fit i.e., 0.75 (Henseler, Ringle \& Sinkovics, 2009; Hair, Ringle, \& Sarstedt, 2013).

Table 3. Construct Reliability and Composite Validity

\begin{tabular}{lcccc}
\hline & $\begin{array}{c}\text { Cronbach's } \\
\text { Alpha }\end{array}$ & rho_A & $\begin{array}{c}\text { Composite } \\
\text { Reliability }\end{array}$ & $\begin{array}{c}\text { Average Variance } \\
\text { Extracted (AVE) }\end{array}$ \\
\hline Innovativeness & 0.718 & 0.766 & 0.788 & 0.558 \\
\hline Moderating Effect TMS - PCS & 1.000 & 1.000 & 1.000 & 1.000 \\
\hline $\begin{array}{l}\text { Perceived Customer } \\
\text { Satisfaction }\end{array}$ & 0.794 & 0.811 & 0.848 & 0.638 \\
\hline Top Management Support & 0.747 & 0.792 & 0.828 & 0.550 \\
\hline
\end{tabular}

Table 3 signifies two important elements associated with descriptive statistics and structural model that are the construct reliability and convergent validity. Composite reliability \& AVE are the criterion to reflect convergent validity (Fornell and Larcker, 1981 \& Sijtsma, 2009 
a\&b). However, AVE has the ability to reflect convergent validity individually (Benitez et al., 2020). The purpose of the tool is to measure the unity of variables in one unified construct (Fornell and Larcker, 1981 \& Sijtsma, $2009 \mathrm{a} \& \mathrm{~b}$ ). The construct reliability has been indicated by Cronbach's alpha, Goldstein rho and composite reliability. However, $\alpha$ is treated as lower tier reliability evaluator (Sijtsma, $2009 \mathrm{a} \& \mathrm{~b}$ ) and rho is better predictor than $\alpha$ (Ravand \& Baghaei, 2016).

Table 4. Discriminant Validity (HTMT Ratio)

\begin{tabular}{lcccc}
\hline & Innovativeness & $\begin{array}{c}\text { Moderating } \\
\text { Effect TMS - } \\
\text { PCS }\end{array}$ & $\begin{array}{c}\text { Perceived } \\
\text { Customer } \\
\text { Satisfaction }\end{array}$ & $\begin{array}{c}\text { Top Management } \\
\text { Support }\end{array}$ \\
\hline Innovativeness & & & \\
\hline Moderating Effect TMS - PCS & 0.066 & & \\
\hline $\begin{array}{l}\text { Perceived Customer } \\
\text { Satisfaction }\end{array}$ & 0.284 & 0.193 & \\
\hline Top Management Support & 0.688 & 0.088 & 0.314 \\
\hline
\end{tabular}

Table 4 shows discriminant validity through Heterotrait-Monotrait Ratio (HTMT). The purpose of discriminant validity is to check the existence of autocorrelation in the variables of the same construct (Cheung \& Lee, 2010). Moreover, the tool is to verify the difference in variables on theoretical as well as statistical grounds. However, HTMT is the most effective method for assessing discriminant validity (Benitez et al., 2020) with 0.85 as the maximum value that is allowed at the junction of two latent variables (Hair Jr., Sarstedt, Ringle, \& Gudergan, 2017).

Table 5. Path-Coefficient (Total Effect)

\begin{tabular}{lccccc}
\hline & $\begin{array}{c}\text { Original } \\
\text { Sample (O) }\end{array}$ & $\begin{array}{c}\text { Sample } \\
\text { Mean (M) }\end{array}$ & $\begin{array}{c}\text { Standard } \\
\text { Deviation } \\
\text { (STDEV) }\end{array}$ & $\begin{array}{c}\text { T Statistics } \\
\text { (|O/STDEV|) }\end{array}$ & P Values \\
\hline $\begin{array}{l}\text { Innovativeness -> } \\
\text { Perceived Customer } \\
\text { Satisfaction }\end{array}$ & 0.138 & 0.150 & 0.070 & 1.989 & 0.047 \\
\hline $\begin{array}{l}\text { Moderating Effect TMS } \\
- \text { PCS -> Perceived } \\
\text { Customer Satisfaction }\end{array}$ & 0.147 & 0.142 & 0.061 & 2.421 & 0.016 \\
\hline $\begin{array}{l}\text { Top Management } \\
\text { Support -> Perceived } \\
\text { Customer Satisfaction }\end{array}$ & 0.221 & 0.237 & 0.067 & 3.330 & 0.001 \\
\hline
\end{tabular}

Table 5 and figure 2 are signifying the path coefficients and regressed impact of innovativeness on customer's satisfaction for the public sector scheduled banks in Pakistan. Table is reflecting inferential statistics to reflect results in against of hypotheses (Benitez et al., 2020). However SMART-PLS needs to incorporate t-statistics (Durate \& Amaro, 2018) \& p-values (Kock \& Hadaya, 2018) to indicate relationship. Although Hair Ringle and Sarstedt (2011) indicated some measures that needs to be indulged with inferential statistics through SMART-PLS. 
According to these measures minimum t-value require for believing in relationship among variables is 1.97 (Hair et al., 2011) and maximum p-value required in this regards is 0.05 (Kock \& Hadaya, 2018). Hence, table as well as figure both is highlighting significant relationship between variables as the minimum t-value reflected is 1.989 . That means innovativeness in public sector scheduled banks is perceived as the predictor of customer's satisfaction. Similarly, moderation of top management support is found to be effective as the value of tstatistics reaches 2.421 in comparison to direct impact (1.989).

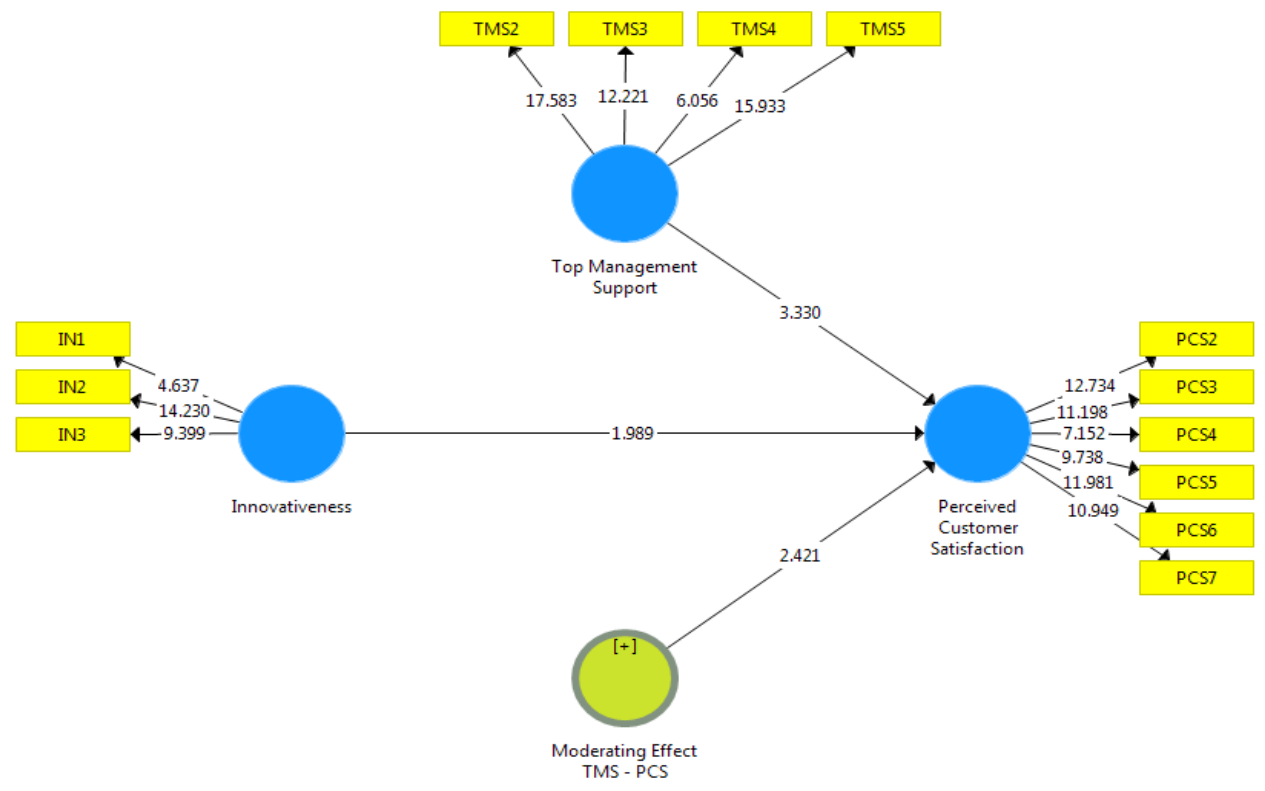

Figure 2. Regression Weights and t-values for the model of innovativeness on customer's satisfaction

\section{CONCLUSION}

On the bases of detailed statistical testing to explore the role of innovativeness on customer's satisfaction of scheduled public sector banks it has been concluded that exploration of the concept is statistically appropriate. This statement is appropriate as innovativeness is consistent with customer's satisfaction in public sector scheduled banks as required by Hasanin (2018) and Ambad and Wahab (2016). Besides, the use of the model also affirms the requirement of innovativeness in emerging markets as required by Demirkan et al. (2019) \& in Asia by Kuratko et al. (2014). Thus, also assures the generation of workable research models in the context of Pakistan as demanded by Nayyar (2017). Hence study fulfills all the claims associated with framework and significance as it proves the linkage between innovativeness and customer satisfaction.

Therefore, it is justifiable to consider the linkage between CE activities in government level companies (GLCs) and customer satisfaction as innovation is also termed as corporate 
entrepreneurship (Hasanin, 2018). Last but not the least study also proved the role of top management support for CE (Carter \& Jones-Evans, 2006) and also assure the role of top as well as middle management in CE of the firm (MacMillan et al., 1984). On the bases of detailed discussion on parameters associated with innovativeness and its role in shaping customer's satisfaction following points are recommended to make future research work effective and pragmatic:

i. Comparison on rate of customer satisfaction through innovativeness with respect to different cities and provinces.

ii. Comparison of customer's satisfaction through innovativeness with respect to different forms of banks like special purpose and others.

iii. Comparison of customer's satisfaction through innovativeness in other government level companies like education and production. 


\section{REFERENCES}

Afthanorhan, W. M. A. B. W. (2014). Hierarchical component using reflective formative measurement model in partial least square structural equation modeling (PLSSEM). International Journal of Mathematics, 2(2), 33-4.

Ahmed, U., Umrani, W. A., Zaman, U., Rajput, S. M., \& Aziz, T. (2020). Corporate Entrepreneurship and Business Performance: The Mediating Role of Employee Engagement. SAGE Open, 10(4), 2158244020962779

Ambad, S. N. A., \& Wahab, K. A. (2016). The relationship between corporate entrepreneurship and firm performance: evidence from Malaysian large companies. International Journal of Business and Society, 17(2), 259-280.

Andreev, P., Heart, T., Maoz, H., \& Pliskin, N. (2009). Validating formative partial least squares (PLS) models: methodological review and empirical illustration. ICIS 2009 proceedings, 193.

Benitez, J., Henseler, J., Castillo, A., \& Schuberth, F. (2020). How to perform and report an impactful analysis using partial least squares: Guidelines for confirmatory and explanatory IS research. Information \& Management, 57(2), 103168.

Carter, S., \& Jones-Evans, D. (Eds.). (2006). Enterprise and small business: Principles, practice and policy. Pearson Education.

Cheah, J. H., Memon, M. A., Chuah, F., \& Ting, H. (2018). Assessing reflective models in marketing research: A comparison between PLS and PLSC estimates. International Journal of Business and Society, 19(1), 139-160.

Cheung, C. M., \& Lee, M. K. (2010). A theoretical model of intentional social action in online social networks. Decision support systems, 49(1), 24-30.

Danişman, A., \& Erkocaoğlan, E. (2007). Corporate entrepreneurship and firm performance: a research study on İstanbul stock exchange firms. İktisat Issletme ve Finans, 22(260), 80101.

Duarte, P., \& Amaro, S. (2018). Methods for modelling reflective-formative second order constructs in PLS. Journal of Hospitality and Tourism Technology, 9(3), 2955-313.

Ferreira, J. (2002, June). Corporate entrepreneurship: a strategic and structural perspective. In International Council for Small Business (Vol. 47, pp. 16-19).

Fornell, C., \& Larcker, D. F. (1981). Evaluating structural equation models with unobservable variables and measurement error. Journal of marketing research, 18(1), 39-50.

Hair Jr, J. F., Sarstedt, M., Ringle, C. M., \& Gudergan, S. P. (2017). Advanced issues in partial least squares structural equation modeling. sage publications.

Hair, J. F., Ringle, C. M., \& Sarstedt, M. (2011). PLS-SEM: Indeed a silver bullet. Journal of Marketing theory and Practice, 19(2), 139-152. 
Hair, J. F., Ringle, C. M., \& Sarstedt, M. (2013). Partial least squares structural equation modeling: Rigorous applications, better results and higher acceptance. Long range planning, 46(1-2), 1-12.

Hair, J. F., Risher, J. J., Sarstedt, M., \& Ringle, C. M. (2019). When to use and how to report the results of PLS-SEM. European Business Review. 31(1), 2-24.

Hasanin, I. A. H. (2020). Investigating the Relationship Between Corporate Entrepreneurship and Customer Loyalty with Customer Satisfaction Mediating Role. International Journal of Marketing Studies, 10(4), 1-94.

Henseler, J., Ringle, C. M., \& Sinkovics, R. R. (2009). The use of partial least squares path modeling in international marketing. New challenges to international marketing. Sinkovics, R.R. and Ghauri, P.N. (Ed.) New Challenges to International Marketing (Advances in International Marketing), 277319. https://doi.org/10.1108/S1474-7979(2009)0000020014.

Ireland, R. D., Kuratko, D. F., \& Morris, M. H. (2006). A health audit for corporate entrepreneurship: innovation at all levels: part II. Journal of Business Strategy, 27(2), 2130 .

Kanter, R. M. (1984). Change masters. innovations and Intrapreneurship in the American corporations. New York, Simon and Schuster.

Karacaoglu, K., Bayrakdaroglu, A., \& San, F. B. (2013). The impact of corporate entrepreneurship on firms' financial performance: Evidence from Istanbul Stock Exchange Firms. International Business Research, 6(1), 163-175.

Kock, N., \& Hadaya, P. (2018). Minimum sample size estimation in PLS-SEM: The inverse square root and gamma-exponential methods. Information Systems Journal, 28(1), 227261.

Leedy, P. D., \& Ormrod, J. E. (2005). Practical Research Planning and Design, New Jersey: Pearson Merrill Prentice Hall.

MacMillan, I. C., Block, Z., \& Narasimha, P. S. (1984). Obstacles and Experiences in Corporate Ventures. New York University, Center for Entrepreneurial Studies.

Moghadam, S. J., \& Salamzadeh, A. (2018). Do senior bankers care about entrepreneurial behaviour? case of senior managers of Iranian vanguard banks. World Review of Entrepreneurship, Management and Sustainable Development, 14(1-2), 271-287.

Moghaddam, J. Y., Khorakian, A., \& Maharati, Y. (2015). Organizational Entrepreneurship and its Impact on the Performance of Governmental Organizations in the City of Mashhad. Procedia-Social and Behavioral Sciences, 169(20), 75-87.

Mugenda, A. (2003). Research methods Quantitative and qualitative approaches by Mugenda. Nairobi, Kenya.

Nayyar, J. (2017). How Corporate Entrepreneurship Can Enhance Organizational Performance in Public Universities of Pakistan? International Journal of Science and Research, 6(2), 2038-2050. 
Nayyar, J., \& Mahmood, R. (2014). The effect of corporate entrepreneurship determinants on performance of public higher education institutions in Pakistan. Business \& Entrepreneurship Journal, 3(1), 19-31.

Peters, T. J., \& Waterman Jr, R. H. (1982). In Search of. Of Excellence, New York: Harper and Row.

Pinchot, G. (1985). Intrapreneuring. Productivity \& Management Review, 16(2), 141-152.

Quinn, J. B. (1985). Managing Innovation: Controlled Chaos. Harward Business Review, 53, 73-84.

Ravand, H., \& Baghaei, P. (2016). Partial least squares structural equation modeling with R. Practical Assessment, Research, and Evaluation,21(1), 11, doi: https://doi.org/10.7275/d2fa-qv48

Saunders, M. N. K., Lewis, P., Thornhill, A., \& Bristow, A. (2015). Understanding research philosophies and approaches: Research methods for business students, ( $8^{\text {th }}$ Edition) Pearson.

Saunders, M., Lewis, P., \& Thornhill, A. (2009). Research methods for business students. Pearson education.

Saunders, M., Lewis, P., \& Thornhill, A. (2012). Research methods for business students (6. utg.). Harlow: Pearson.

Sebora, T. C., \& Theerapatvong, T. (2010). Corporate entrepreneurship: A test of external and internal influences on managers' idea generation, risk taking, and proactiveness. International Entrepreneurship and Management Journal, 6(3), 331-350.

Sekaran, U., \& Bougie, R. (2016). Research methods for business: A skill building approach. John Wiley \& Sons.

Shaikh, S. (2020). Challenges faced by women owned micro, small and medium enterprises in an emerging economy. International Journal of Management, 11(7).

Sharma, D. J. (2017). A study on innovation in banking and its impact on customer satisfaction. IOSR Journal of Economics and Finance, 1(1), 70-74.

Sijtsma, K. (2009a). On the use, the misuse, and the very limited usefulness of Cronbach's alpha. Psychometrika, 74(1), 107.

Sijtsma, K. (2009b). Over misverstandenrond Cronbachs alfa en de wenselijkheid vanalternatieven. Psycholoog, 44(11), 561.

Sileyew, K. J. (2019). Research Design and Methodology. In Text Mining-Analysis, Programming and Application. Intech Open, https://www.intechopen.com/books/cyberspace/research-design-and-methodology

Sinkovics, R. R., Richter, N. F., Ringle, C. M., \& Schlägel, C. (2016). A critical look at the use of SEM in international business research. International marketing review, 33(3), 376404. https://doi.org/10.1108/IMR-04-2014-014 
State Bank of Pakistan (n.d.). retrieved from https://www.sbp.org.pk

Umrani, W. A., Kura, K. M., \& Ahmed, U. (2018). Corporate entrepreneurship and business performance. PSU Research Review, 2(1), 59-80.

Žukauskas, P., Vveinhardt, J., \& Andriukaitienè, R. (2018). Philosophy and paradigm of scientific research. Management Culture and Corporate Social Responsibility, 121. 